Open Access

\title{
Measuring foreign language anxiety among learners of different foreign languages: in relation to motivation and perception of teacher's behaviors
}

Fatmawati Djafri ${ }^{1,2^{*}}$ (D) and Supra Wimbarti ${ }^{3}$

\author{
* Correspondence: \\ fatmawati.djafri@gmail.com \\ 'Japanese Language Program, \\ Sekolah Vokasi, Universitas Gadjah \\ Mada, Yogyakarta, Indonesia \\ ${ }^{2}$ Graduate School of International \\ Culture and Communication Studies \\ (GSICCS) Waseda University, 1-6-1 \\ Nishiwaseda, Shinjuku, Tokyo \\ 169-8050, Japan \\ Full list of author information is \\ available at the end of the article
}

\begin{abstract}
This study investigates foreign language anxiety among Indonesian undergraduate students of English, French, Japanese, Korean and Arabic language programs, and examines its relationship with students' motivation and their perception of teachers' behaviors. Questionnaires were distributed to 182 s-grade undergraduate students majoring in five foreign languages at an Indonesian public university. One-way ANOVA analysis revealed that learners of Japanese have the highest foreign language anxiety level compared to others. Furthermore, using independent sample T-test method, it showed that learners of non-Latin languages group (Japanese, Korean, and Arabic) have a higher foreign language anxiety level than those of Latin language group (English and French). The relationship between foreign language anxiety, learners' motivation and their perception of teachers' behaviors, was analyzed using a multiple-regression method, and the finding indicated that learners' motivation does not affect foreign language anxiety. Meanwhile, their perception of teacher's behaviors significantly affects foreign language anxiety. Based on the results, the present study suggests that foreign language teachers should give more attention to their teaching method and behaviors applied inside the classroom, and on how to create a more conducive learning environment in the classroom in order to reduce foreign language anxiety experienced by their students.
\end{abstract}

Keywords: Foreign language anxiety, Motivation, Perception of teacher's behaviors, Language learners, Latin languages, Non-Latin languages

\section{Introduction}

Foreign language anxiety is a universal phenomenon that is not just found in English language classroom (Kondo, 2005; Sila, 2010), but also in other languages such as Spanish (Noels, 2001) or French (Rodríguez \& Abreu, 2003), and among less commonly taught languages, including Arabic and Japanese (Elkhafaifi, 2005; William \& Andrade, 2008). There are many aspects of foreign language learning that could provoke anxiety in students. In the framework of the socio-educational model of foreign language learning, foreign language anxiety is one of the parts measured in the Attitudes/ Motivation Test Battery, which indicates a link between motivation and anxiety (Gardner, 1985). Kitano (2001) also suggested that strongly motivated students often experience a 
high level of language anxiety. Students' negative perception of teachers' behaviors was found to be related to higher foreign language anxiety in the classroom (Noels et al., 1999). Moreover, the different writing and phonological system (Elkhafaifi, 2005) compared to the native language and the unknown linguistic and socio-cultural standards (Horwitz et al., 1986) of the foreign language may also contribute to the occurrence of foreign language anxiety. This study reports on a quantitative study conducted to measure and compare foreign language anxiety among learners of English, French, Japanese, Korean, and Arabic in an Indonesian university and to examine the effect of students' motivation and their perception of teacher's behaviors on foreign language anxiety experienced by different foreign language learners.

\section{Literature review}

Foreign language anxiety is a situation-specific anxiety arising from the uniqueness of the formal learning of foreign language, especially in low self-appraisal of communicative abilities in that language (Rodríguez \& Abreu, 2003). Studies from Kleinmann and also from Steinberg and Horwitz (in Horwitz et al., 1986) have indicated that anxiety can affect the communication strategies students employed in the language class. Yoshida (2010) stated that students frequently enter the foreign language classroom with anxiety. Whilst, Tsiplakides and Keramida (2009) found that students who experience anxiety in the classroom were unwilling to participate in speaking activities because they believe that they were not good at speaking and feared that their classmates would evaluate them negatively.

Horwitz et al. (1986) suggest three components of foreign language anxiety, namely communication apprehension, test anxiety, and fear of negative evaluation. Communication apprehension is defined as fear or anxiety in communicating with people, manifested in oral communication anxiety within a group or in public, or difficulty in listening to a spoken message. Test anxiety refers to a type of performance anxiety stemming from a fear of failure. Fear of negative evaluation is apprehension about others' evaluations, avoidance of evaluative situations, and the expectation that others would evaluate one negatively. These three components were employed to measure the foreign language anxiety occurred in foreign language classroom, using Foreign Language Classroom Anxiety Scale (FLCAS) developed by Horwitz et al. (1986).

Previous studies have found many factors that influence foreign language anxiety. Among those factors are students' motivation to learn (Bandura, 1997), students' belief about language acquisition (Horwitz et al., 1986), students' personalities (Dewaele \& Furnham, in Duxbury \& Tsai, 2010), the way teachers interact with students (Vygotsky, in Duxbury \& Tsai, 2010), students' background in the language (Frantzen \& Magnan, in Duxbury \& Tsai, 2010), and learning in cooperative groups (Oxford, in Duxbury \& Tsai, 2010). The different writing and phonological system (Elkhafaifi, 2005) compared to the native language and the unknown linguistic and socio-cultural standards (Horwitz et al., 1986) of the foreign language may also contribute to the occurrence of foreign language anxiety.

Social factors such as classroom atmosphere, teacher-student relationship, student-student relationship, the opportunity for making contact with target language members, and also the risk of embarrassment were also recognized as factors which might induce language anxiety (MacIntyre, 1995). Noels et al. (1999) found that students' perception of teachers as 
autonomy-supportive and providing informative feedback could increase students' intrinsic motivation which relates to positive language learning outcomes, motivational intensity, self-evaluation of competence, and the reduction of anxiety. Ehrman (in Katsuhisa \& Masahide, 2006) also reported that intrinsic motivation is associated with lower anxiety, increasing self-efficacy, and positive attitude toward language learning. Other study found that students' positive attitudes toward their second language teachers were associated with their linguistic self-confidence and anxiety (Noels, 2001).

The dynamic relationship between foreign language anxiety, motivation and perception of teachers' behaviors among learners of various foreign languages in Indonesian context has not been extensively studied. The foreign language learning experiences of Indonesian language learners who has multilingual background is interesting to be further explored, particularly in relation to the foreign language learning with different writing and phonological system compared to Bahasa Indonesia (Indonesian language) and various regional languages spoken in different regions in Indonesia. Therefore, the aim of this study is to answer the following research questions related to foreign language anxiety among Indonesian learners of different foreign languages:

1. To what extent does foreign language anxiety is manifested in Indonesian learners of English, Japanese, Korean, French, and Arabic?

2. Is there a difference in foreign language anxiety level between Latin languages group (English and French) and non-Latin language group (Japanese, Korean, and Arabic)?

3. How did the foreign language anxiety relate to students' motivation and their perception of teachers' behaviors among Indonesian learners of different foreign languages?

\section{Methods}

\section{Foreign language anxiety scale}

The questionnaire is to measure students' anxiety level in their foreign language classroom. The present study will adapt Foreign Language Classroom Anxiety Scale (FLCAS) from Horwitz et al. (1986), which was used to assess students' anxiety in Spanish class and has been translated into Indonesian language. The original questionnaire consists of 33 statements, of which 8 items to measure communication anxiety, 9 items to measure fear of negative evaluation, 5 items to measure test anxiety, and 11 items to measure anxiety of foreign class. The present study has modified the original version by adding some statements into four measured aspects, so then each aspect contains 10 statements in which are divided into five favorable statements and five unfavorable ones (see Additional file 1). All indicators of the foreign language anxiety scale are provided in the statement sentences of favourable and unfavourable, with five choices of responses: strongly agree (sangat setuju - SS), agree (setuju - S), neutral (netral - N), disagree (tidak setuju - TS), strongly disagree (sangat tidak setuju - STS). The subjects of the study will be asked to give a response to every statement given. The score range is from 1 to 5 , with the scoring for favourable statements: $S S=5, S=4, N=3, T S=2, S T S=1$, and for unfavourable statements: $S S=1, S=2, N=3, T S=4, S T S=5$. After try-out and 
analysis, the questionnaire was reduced to 34 items with item-total correlation coefficients ranging from 0.303 to 0.696 , and alpha reliability coefficient 0.933 .

\section{Student's motivation scale}

The questionnaire is adapted from Language Learning Orientation Scale (LLOS) constructed by Noels et al. (2003). The scale is used to measure students' motivation, including intrinsic motivation, extrinsic motivation and amotivation. The original version of LLOS consists of 21 statements projected seven subscales: i.e. amotivation; external regulation, introjected regulation, and identified regulation as parts of extrinsic motivation; and knowledge, accomplishment, and stimulation as parts of intrinsic motivation. The modified version used in the present study, which was written in Indonesian language, consists of 36 items that were reduced to 22 items after try-out and analysis, with item-total correlation coefficients ranging from 0.301 to 0.569 , and alpha reliability coefficient 0.866 . All indicators of the student's motivation scale are provided in the statement sentences of favorable and unfavorable, with five choices of responses, similar with the foreign language anxiety scale (see Additional file 1).

\section{Students' perception of teachers' behaviors scale}

The questionnaire for the present research was made based on previous researches conducted by Noels et al. (1999) on the perception of teacher's communication styles, and by Pelletier and Vallerand (1996) on the relation of teachers' behaviors and students' intrinsic motivation using a behavioral confirmation analysis. The scale in Indonesian language consists of 20 statements of which 10 statements measure students' perception of teachers' behaviors as controlling and authoritarian, and the remaining 10 statements measure students' perception of teachers' behaviors as autonomy-supportive and providing feedback in a positive, informative manner. After try-out and analysis, the questionnaire was reduced to 9 items with item-total correlation coefficients ranging from 0.453 to 0.663 , and alpha reliability coefficient 0.845 . All indicators of the students' perception of teachers' behaviors scale are provided in the statement sentences of favorable and unfavorable, with five choices of responses, similar to the previous scales (see Additional file 1).

\section{Open-ended questions}

Open-ended questions used in the present research were modified from the previous research conducted by Williams and Andrade (2008) on Japanese students in English classroom. There are four questions in Indonesian language. The first one asked participants to describe in detail the situation or event that will provoke their anxiety in the foreign language classroom. The second question asked participants to give a check mark on the items' list of the people who they feel is the most responsible for the anxiety-provoking situation or event they described earlier. The third question asked participants to measure their own foreign language performance in the described anxious moment, from 1 (poor) to 5 (excellent). The last one asked participants to explain the reason for their choosing the foreign language course they are in now and their plan after graduating from the course (see Additional file 1). 


\section{Participants' background information}

Background information used in the present study is to find out about participants' personal information, especially in relation to the foreign language they are learning. It asked participants some information concerning their gender, ethnicity, what language is used within the family members, and other foreign languages learning history (see Additional file 1). The information is highly beneficial to enrich the result of the data analysis.

\section{Participants}

Research participants are 182 s-grade undergraduate students majoring in five foreign language programs at an Indonesian university, who consist of:

- 30 students of English $\{7$ males (23.33\%) and 23 females (76.67\%)\}

- 47 students of Japanese $\{14$ males (29.79\%) and 33 females $(70.21 \%)\}$

- 32 students of Arabic $\{10$ males (31.25\%) and 22 females (68.75\%)\}

- 43 students of French $\{10$ males (23.26\%) and 33 females (76.74\%) $\}$

- 30 students of Korean $\{6$ males (20\%) and 24 females (80\%) $\}$

Second-grade students were chosen as participants with assumption that they are now in intermediate level of second language learning, with increased difficulties of foreign language learning compared to basic level, and where bigger challenges start to reveal themselves. In comparison, first-grade students are still in transition period from high school to university, and still have the excitement of being freshmen and studying new language. Moreover, they encounter the introductory level of language learning, which is less difficult than the intermediate one. On the other end, third-grade students are already passed the basic and intermediate level and now entering the advanced one. They were assumed to be more at ease in facing the increased difficulty of language learning due to the previous experiences and already built their own strategy to deal with the barrier.

\section{Data collection and analysis}

The data collection was conducted with the help of teachers of each foreign language classrooms. After explaining about the research and ethical issues and asking for students' consent to be research participants, the author distributed sets of questionnaires to students at the end of each class and gave students 20-30 min to fill in the questionnaires. Those who agreed to participate in the study were asked to submit the completed questionnaires to the author before leaving the class.

\section{Results}

Foreign language anxiety among learners of English, French, Japanese, Korean and Arabic One-way ANOVA was used to examine the difference in foreign language anxiety level between learners of English, French, Japanese, Korean, and Arabic. The mean scores as shown in Table 1 reveal that Japanese learners have the biggest foreign language anxiety (100.30) among others, i.e. Arabic (92.59), French (91.63), Korean (90.30), and English (83.07). The result of ANOVA Test in Table 2 also shows $F=4.865$ and p (sig.) $=0.001$ or $p<0.05$. 
Table 1 Descriptive Data of Foreign Language Anxiety Scale

\begin{tabular}{|c|c|c|c|c|c|c|c|c|}
\hline & \multirow[t]{2}{*}{ N } & \multirow[t]{2}{*}{ Mean } & \multirow[t]{2}{*}{ Std. Deviation } & \multirow[t]{2}{*}{ Std. Error } & \multicolumn{2}{|c|}{ 95\% Confidence Interval for Mean } & \multirow[t]{2}{*}{ Minimum } & \multirow[t]{2}{*}{ Maximum } \\
\hline & & & & & Lower Bound & Upper Bound & & \\
\hline Inggris & 30 & 83.07 & 20.027 & 3.656 & 75.59 & 90.55 & 47 & 137 \\
\hline Jepang & 47 & 100.30 & 15.503 & 2.261 & 95.75 & 104.85 & 71 & 127 \\
\hline Arab & 32 & 92.59 & 17.067 & 3.017 & 86.44 & 98.75 & 49 & 121 \\
\hline Perancis & 43 & 91.63 & 18.776 & 2.863 & 85.85 & 97.41 & 59 & 126 \\
\hline Korea & 30 & 90.30 & 13.596 & 2.482 & 85.22 & 95.38 & 56 & 113 \\
\hline Total & 182 & 92.41 & 17.837 & 1.322 & 89.80 & 95.02 & 47 & 137 \\
\hline
\end{tabular}

Furthermore, the researcher used post-hoc test to investigate which of the paired sample groups is significantly different (see Table 3). It was inferred from the result that there is a significant difference of anxiety between English and Japanese students $(p=0.000)$, in which Japanese students has a bigger anxiety than English students (mean difference = 17.231). Whilst, other paired sample groups show no significant differences.

Foreign language anxiety between Latin language group and non-Latin language groups Independent sample T-test was used to compare the foreign language anxiety level between Latin languages group (English and French) with non-Latin languages group (Japanese, Korean and Arabic). The results in Table 4 and Table 5 show that there is a significant difference of foreign language anxiety between Latin and non-Latin sample group with sig. (2-tailed) $=0.007$ or $p<0.05$, in which non-Latin sample group (mean $=95.28)$ has a higher anxiety than Latin one (mean $=88.11)$.

Foreign language anxiety, Student's motivation, and their perception of Teacher's behaviors Multiple regression analysis with backward method was used to investigate the relationship between foreign language anxiety, student's motivation, and their perception of teacher's behaviors. The result shows that student's motivation is removed in model 2 . Table 6 and Table 7 show the $\mathrm{R}$ square value $=0.026$ and $p=0.095$, or $p>0.05$. It suggests that student's motivation and their perception of teacher's behaviors do not simultaneously affect foreign language anxiety. Furthermore, R square shows value of 0.026, means that student's motivation and student's perception of teacher's behaviors contribute only $2.6 \%$ to predict foreign language anxiety.

In model 1 where student's motivation variable is included, the coefficient of student's motivation has $p$-value $=0.863$ or $\mathrm{p}>0.05$. Thus, student's motivation does not significantly affect foreign language anxiety. Meanwhile, the variable of student's perception of teacher's behaviors in model 1 has $p=0.035$ or $p<0.05$. It means that the variable significantly affects foreign language anxiety. In model 2 after student's motivation variable has been removed, the p-value increases to 0.030 and the Beta values has increased

Table 2 ANOVA of Foreign Language Anxiety Scale

\begin{tabular}{llllll}
\hline & Sum of Squares & df & Mean Square & F & Sig. \\
\hline Between Groups & 5704.150 & 4 & 1426.038 & 4.865 & .001 \\
Within Groups & $51,883.762$ & 177 & 293.129 & & \\
Total & $57,587.912$ & 181 & & & \\
\hline
\end{tabular}


Table 3 Post-Hoc Test of Foreign Language Anxiety Scale

\begin{tabular}{|c|c|c|c|c|c|c|c|}
\hline \multicolumn{8}{|c|}{ Multiple Comparisons } \\
\hline \multicolumn{8}{|c|}{ Dependent Variable: anxiety } \\
\hline & \multirow[t]{2}{*}{ (I) jurusan } & \multirow[t]{2}{*}{ (J) jurusan } & \multirow{2}{*}{$\begin{array}{l}\text { Mean } \\
\text { Difference } \\
(I-J)\end{array}$} & \multirow[t]{2}{*}{ Std. Error } & \multirow[t]{2}{*}{ Sig. } & \multicolumn{2}{|c|}{ 95\% Confidence Interval } \\
\hline & & & & & & Lower Bound & Upper Bound \\
\hline \multirow[t]{20}{*}{$\overline{\text { Tukey HSD }}$} & \multirow[t]{4}{*}{ inggris } & jepang & $-17.231^{\mathrm{a}}$ & 4.001 & .000 & -28.26 & -6.20 \\
\hline & & arab & -9.527 & 4.351 & .188 & -21.52 & 2.46 \\
\hline & & perancis & -8.561 & 4.073 & .224 & -19.79 & 2.66 \\
\hline & & korea & -7.233 & 4.421 & .476 & -19.42 & 4.95 \\
\hline & \multirow[t]{4}{*}{ jepang } & inggris & $17.231^{\mathrm{a}}$ & 4.001 & .000 & 6.20 & 28.26 \\
\hline & & arab & 7.704 & 3.924 & .288 & -3.11 & 18.52 \\
\hline & & perancis & 8.670 & 3.613 & .120 & -1.29 & 18.63 \\
\hline & & korea & 9.998 & 4.001 & .095 & -1.03 & 21.02 \\
\hline & \multirow[t]{4}{*}{ arab } & inggris & 9.527 & 4.351 & .188 & -2.46 & 21.52 \\
\hline & & jepang & -7.704 & 3.924 & .288 & -18.52 & 3.11 \\
\hline & & perancis & .966 & 3.997 & .999 & -10.05 & 11.98 \\
\hline & & korea & 2.294 & 4.351 & .984 & -9.70 & 14.29 \\
\hline & \multirow[t]{4}{*}{ perancis } & inggris & 8.561 & 4.073 & .224 & -2.66 & 19.79 \\
\hline & & jepang & -8.670 & 3.613 & .120 & -18.63 & 1.29 \\
\hline & & arab & -.966 & 3.997 & .999 & -11.98 & 10.05 \\
\hline & & korea & 1.328 & 4.073 & .998 & -9.90 & 12.55 \\
\hline & \multirow[t]{4}{*}{ korea } & inggris & 7.233 & 4.421 & .476 & -4.95 & 19.42 \\
\hline & & jepang & -9.998 & 4.001 & .095 & -21.02 & 1.03 \\
\hline & & arab & -2.294 & 4.351 & .984 & -14.29 & 9.70 \\
\hline & & perancis & -1.328 & 4.073 & .998 & -12.55 & 9.90 \\
\hline \multirow[t]{20}{*}{ Bonferroni } & \multirow[t]{4}{*}{ inggris } & jepang & $-17.231^{a}$ & 4.001 & .000 & -28.60 & -5.86 \\
\hline & & arab & -9.527 & 4.351 & .299 & -21.90 & 2.84 \\
\hline & & perancis & -8.561 & 4.073 & .370 & -20.14 & 3.02 \\
\hline & & korea & -7.233 & 4.421 & 1.000 & -19.80 & 5.33 \\
\hline & \multirow[t]{4}{*}{ jepang } & inggris & $17.231^{\mathrm{a}}$ & 4.001 & .000 & 5.86 & 28.60 \\
\hline & & arab & 7.704 & 3.924 & .512 & -3.45 & 18.86 \\
\hline & & perancis & 8.670 & 3.613 & .174 & -1.60 & 18.94 \\
\hline & & korea & 9.998 & 4.001 & .134 & -1.38 & 21.37 \\
\hline & \multirow[t]{4}{*}{ arab } & inggris & 9.527 & 4.351 & .299 & -2.84 & 21.90 \\
\hline & & jepang & -7.704 & 3.924 & .512 & -18.86 & 3.45 \\
\hline & & perancis & .966 & 3.997 & 1.000 & -10.40 & 12.33 \\
\hline & & korea & 2.294 & 4.351 & 1.000 & -10.07 & 14.66 \\
\hline & \multirow[t]{4}{*}{ perancis } & inggris & 8.561 & 4.073 & .370 & -3.02 & 20.14 \\
\hline & & jepang & -8.670 & 3.613 & .174 & -18.94 & 1.60 \\
\hline & & arab & -.966 & 3.997 & 1.000 & -12.33 & 10.40 \\
\hline & & korea & 1.328 & 4.073 & 1.000 & -10.25 & 12.91 \\
\hline & \multirow[t]{4}{*}{ korea } & inggris & 7.233 & 4.421 & 1.000 & -5.33 & 19.80 \\
\hline & & jepang & -9.998 & 4.001 & .134 & -21.37 & 1.38 \\
\hline & & arab & -2.294 & 4.351 & 1.000 & -14.66 & 10.07 \\
\hline & & perancis & -1.328 & 4.073 & 1.000 & -12.91 & 10.25 \\
\hline
\end{tabular}

${ }^{\text {TThe mean difference is significant at the } .05 \text { level }}$ 
Table 4 Mean Differences between Alphabetic and Non-Alphabetic

\begin{tabular}{llllll}
\hline Language & & $N$ & Mean & Std. Deviation & Std. Error Mean \\
\hline Foreign language anxiety & alphabetic & 73 & 88.11 & 19.626 & 2.297 \\
& non-alphabetic & 109 & 95.28 & 15.987 & 1.531 \\
\hline
\end{tabular}

as well from 0.159 to 0.160 in which indicate that model 2 without student's motivation is better than model 1 (Table 8).

\section{Findings from open-ended questions}

In addition to the three main instruments implemented in the present study, open-ended questions were also employed to get a more comprehensive information on the relationship between foreign language anxiety, motivation and perception of teacher's behaviors experienced by participants of the study. Situations inflicted anxiety is categorized into four categories which related to several factors: assignment, teacher, native speaker, and language class (Table 9).

In Japanese learners, 22 subjects (48\%) chose teacher-related situation as the biggest cause of anxiety, followed by class-related situation $(N=15,33 \%)$. The similar pattern found in other languages learners as well, i.e. Korean (teacher-related 50\%, class-related 25\%), French (teacher-related 53\%, class-related 31\%), and Arabic (teacher-related 55\%, class-related 37\%). The only exception was English learners, in which 12 subjects (44\%) chose class-related situation as the biggest cause of anxiety, while the assignment- and teacher-related situations shared the same proportion $(N=7,25 \%)$.

In contrast, the data on factors of which participants perceived as responsible for inflicting their anxiety, as presented in Table 10, showed a different result. Most participants in five foreign language programs blamed themselves as the one who was responsible for the occurrence of the anxiety.

Regarding the language performance during the anxious state, most participants also perceived their foreign language ability in average/low level when they get anxious in foreign language classroom (Table 11).

Meanwhile, regarding the motivation for taking foreign language program, interest in studying foreign language and culture became the main reason for most participants in choosing the foreign language study program at Indonesian university, as shown in

Table 5 Independent Sample T-Test between Latin and Non-Latin Language Groups

\begin{tabular}{|c|c|c|c|c|c|c|c|c|c|c|}
\hline \multicolumn{11}{|c|}{ Independent Samples Test } \\
\hline & & \multicolumn{2}{|c|}{$\begin{array}{l}\text { Levene's } \\
\text { Test for } \\
\text { Equality of } \\
\text { Var iances }\end{array}$} & \multicolumn{7}{|c|}{ t- test for Equality of Means } \\
\hline & & \multirow[t]{2}{*}{$F$} & \multirow[t]{2}{*}{ Sig. } & \multirow[t]{2}{*}{$\mathrm{t}$} & \multirow[t]{2}{*}{ df } & \multirow[t]{2}{*}{$\begin{array}{l}\text { Sig. } \\
\text { (2-tailed) }\end{array}$} & \multirow[t]{2}{*}{$\begin{array}{l}\text { Mean } \\
\text { Difference }\end{array}$} & \multirow[t]{2}{*}{$\begin{array}{l}\text { Std. Error } \\
\text { Difference }\end{array}$} & \multicolumn{2}{|c|}{$\begin{array}{l}95 \% \text { Confidence } \\
\text { Inter val of the } \\
\text { Difference }\end{array}$} \\
\hline & & & & & & & & & Lower & Upper \\
\hline \multirow{2}{*}{$\begin{array}{l}\text { Foreign } \\
\text { language } \\
\text { anxiety }\end{array}$} & $\begin{array}{l}\text { Equal var. } \\
\text { iances assumed }\end{array}$ & 1.622 & .204 & -2.706 & 180 & .007 & -7.175 & 2.652 & -12.407 & -1.942 \\
\hline & $\begin{array}{l}\text { Equal var. } \\
\text { iances not } \\
\text { assumed }\end{array}$ & & & -2.599 & 132.738 & .010 & -7.175 & 2.761 & -12.635 & -1.714 \\
\hline
\end{tabular}


Table 6 R-value of Independent Variables

\begin{tabular}{lllll}
\hline Model & $R$ & R Square & Adjusted R Square & Std. Error of the Estimate \\
\hline 1 & $.161(\mathrm{a})$ & .026 & .015 & 17.703 \\
2 & $.160(\mathrm{~b})$ & .026 & .020 & 17.655 \\
\hline
\end{tabular}

Table 12. The result reflected high intrinsic motivation of participants towards the foreign language of their choice. Furthermore, approximately 87\% of English learners were also taking English informal language course, followed by $70 \%$ of French learners taking French informal language course, Korean language 37\%, Japanese language 21\%, and Arabic language 16\%. The significant percentages, particularly learners of English and French, also indicated high motivation towards foreign language learning.

\section{Discussion}

\section{Foreign language anxiety among learners of English, Japanese, Korean, French, and Arabic}

The present research found that there is a difference in foreign language anxiety level among second-grade undergraduates of five foreign language study programs. Japanese learners have the highest level of foreign language anxiety, followed by Arabic, French, Korean, and English learners. One possible explanation about the finding is that the level of difficulty in Japanese, especially in reading and writing, increases at the same time with the level of the class, i.e. beginner, intermediate, and advanced levels. At the beginner level, students are required to master three different Japanese characters, i.e. Hiragana, Katakana, and simple Kanji. For the intermediate and advanced levels, the requirement is still the same, in addition to more complex Kanji characters. Reading and writing are closely intertwined, so the lack of ability in one of them will affect the other as well. A research by Saito and Samimy (1996) suggested that the emphasis on reading and orthography was greatly increased in Japanese advanced classes and thus contributed to increasing anxiety. Kitano (2001) suggests that student's greater awareness of their own errors and the increased use of Japanese in the classroom might account for the higher level of anxiety of advanced students than beginning students. Whilst in the case of Arabic, reading and orthographical tasks do not undergo a similar increase in difficulty because the alphabets acquired during the initial period of instruction remain the same (Elkhafaifi, 2005). Furthermore, Elkhafaifi also reported that students of Arabic in the third year have significantly lower level of anxiety than first-year students.

Table 7 Regression Coefficients of Independent Variables

\begin{tabular}{lllllll}
\hline ANOVA $^{\mathrm{C}}$ & \multicolumn{7}{c}{} & & & & \\
\hline Model & & Sum of Squares & $\mathrm{df}$ & Mean Square & $\mathrm{F}$ & Sig. \\
\hline 1 & Regression & 1492.336 & 2 & 746.168 & 2.381 & $.095^{\text {a }}$ \\
& Residual & 56095.576 & 179 & 313.383 & & \\
& Total & 57587.912 & 181 & & & \\
2 & Regression & 1482.967 & 1 & 1482.967 & 4.758 & $.030^{\text {b }}$ \\
& Residual & 56104.945 & 180 & 311.694 & & \\
& Total & 57587.912 & 181 & & & \\
\hline
\end{tabular}

Predictors: (Constant), student's percept ion, student's a. motivation

bPredictors: (Constant), student's perception

'Dependent Variable: foreign language anxiety 
Table 8 Partial Coefficients of Each Independent Variable

\begin{tabular}{|c|c|c|c|c|c|c|}
\hline \multicolumn{7}{|c|}{ Coefficients $^{a}$} \\
\hline \multicolumn{2}{|c|}{ Model } & \multicolumn{2}{|c|}{ Unstandardized Coefficients } & \multirow{2}{*}{$\begin{array}{l}\text { Standardized Coefficients } \\
\text { Beta }\end{array}$} & \multirow[t]{2}{*}{$\mathrm{t}$} & \multirow[t]{2}{*}{ Sig. } \\
\hline & & $B$ & Std. Error & & & \\
\hline \multirow[t]{3}{*}{1} & (Constant) & 58.272 & 17.653 & & 3.301 & .001 \\
\hline & student's motivation & .024 & .138 & .013 & .173 & .863 \\
\hline & student's perception & 1.037 & .488 & .159 & 2.124 & .035 \\
\hline \multirow[t]{2}{*}{2} & (Constant) & 59.879 & 14.970 & & 4.000 & .000 \\
\hline & student's perception & 1.050 & .481 & .160 & 2.181 & .030 \\
\hline
\end{tabular}

a. Dependent Variable: foreign language anxiety

However, in the present study, Arabic learners show a relatively high level of foreign language anxiety compared to French, Korean and English, despite the fact that Arabic has been a familiar foreign language learned by most Indonesian people (Moslem) since childhood. One possible explanation for it was laid on the difference of the environment where Arabic was learned. Most Indonesian children started to learn reading Arabic (Koran) in more informal environment, such as at a mosque or at the teacher's house, which is less tense compared to classroom environment at the university level. Besides, the demand for university students is bigger since the language study also incorporates with other special fields as well, such as literature, linguistics, and history, and it may provoke anxiety. Further analysis in the present study also found that there is a significant difference between Japanese and English in the level of foreign language anxiety. The finding might occur because of the difference between the nature of the languages. As explained earlier, Japanese has different writing system compared to Bahasa Indonesia used as the common language by most Indonesians. In studying Japanese, students have to master three kinds of alphabets, i.e. Hiragana, Katakana and Kanji. According to Agency for Cultural Affairs Government of Japan (Bunkacho, 2010), there are 2136 Kanji characters regularly used in everyday life that are required to be learned. In addition, the grammar also becomes more difficult in intermediate and advanced level. Therefore, the anxiety is more likely to occur in Japanese. Meanwhile, students of English are facing less heavy tasks, because the writing system is using alphabet, similar with Bahasa Indonesia. Other research suggests that even though students are studying foreign language with different writing system from their native language, they may feel less anxious if they are not expected to be highly competent in the language. A research by Liu and Huang (2011) on 980 undergraduate students of three universities in China who enroll in English course found result in which the respondents generally did not feel anxious in English. It concluded that over-emphasizing English learning for utilitarian purposes might cause pressure and provoke anxiety in learners. The stressing on highly competency and utilitarian purpose

Table 9 Situations causing anxiety

\begin{tabular}{llllll}
\hline Factors & Korean & French & Arabic & Japanese & English \\
\hline Assignment-related & 5 & 6 & 2 & 2 & 7 \\
Teacher-related & 14 & 22 & 15 & 22 & 7 \\
Native speaker-related & 2 & - & - & 6 & 1 \\
Class-related & 7 & 13 & 10 & 15 & 12 \\
\hline
\end{tabular}


Table 10 Perceived responsible for the anxiety

\begin{tabular}{llllll}
\hline Factors & Korean & French & Arabic & Japanese & English \\
\hline Self & 19 & 34 & 19 & 33 & 19 \\
Teacher & 5 & 6 & 8 & 9 & 4 \\
Fate & 4 & 1 & - & 2 & 4 \\
Institution & 1 & - & 3 & 1 & 1 \\
Chance & 1 & 1 & - & 1 & 1 \\
Classmate & - & 1 & - & - & - \\
Native speaker & - & - & - & - & - \\
All & - & - & 1 & &
\end{tabular}

of the language, along with the different writing system between Japanese and Bahasa Indonesia, may become the cause of high level of anxiety among Japanese learners. In addition to it, findings from open-ended questions in the present study revealed that most students of English have already learned the language previously at various language courses and have English-speaking native friends. Both experiences, along with the nature of the languages, might contribute significantly to the level of foreign language anxiety. Tajima (2002) suggested that there is a difference in anxiety levels between students who previous experiences including having native-speaking friends or traveling abroad and they who had not.

Foreign language anxiety level between Latin languages group (English and French) and non-Latin languages group (Japanese, Korean, and Arabic)

The present study also found a significant difference of foreign language anxiety between Latin and non-Latin language learners. Non-Latin languages group, namely Japanese, Arabic, and Korean, has a higher level of anxiety compared to Latin languages group, namely English and French. The finding confirms the hypothesis that different writing system will increase foreign language anxiety. Indonesian students are more familiar with Latin language since Bahasa Indonesia is also using the similar system. Therefore, learners of foreign languages with non-Latin alphabet system will have a greater possibility to experience foreign language anxiety. This is similar to the research conducted by Saito et al. (1999), who found that students experience anxiety whenever they encounter unfamiliar words and different writing systems in a reading text. This is also consistent with earlier research by Horwitz et al. (1986) who found that the unknown linguistic standard also influences foreign language anxiety.

Foreign language anxiety, Student's motivation, and their perception of teachers' behaviors The present study discovered that motivation does not significantly affect foreign language anxiety. Previous researches presumed that the two variables are related to one

Table 11 Perceived ability when anxious

\begin{tabular}{llllll}
\hline Level of language performance & Korean & French & Arabic & Japanese & English \\
\hline High (4-5) & 3 & 7 & 5 & - & 5 \\
Average (3) & 20 & 20 & 9 & 24 & 15 \\
Low (1-2) & 7 & 17 & 17 & 23 & 10 \\
\hline
\end{tabular}


Table 12 Reasons in choosing the foreign language

\begin{tabular}{llllll}
\hline Main motivations & Korean & French & Arabic & Japanese & English \\
\hline Interest & 12 & 19 & 16 & 30 & 18 \\
Work prospect & 13 & 12 & 3 & 8 & 7 \\
Last option/parent's choice & 5 & 13 & 13 & 7 & 5 \\
\hline
\end{tabular}

another, some found negative association between motivation and language learning anxiety (Gardner \& MacIntyre, 1993), others found potential positive relationship in which highly motivated students was associated with high level of anxiety (Kitano, 2001). However, previous studies have not clearly defined the functional relationship between foreign language anxiety and motivation (MacIntyre, 2002). Tóth (2007) has investigated the relationship between foreign language anxiety and other individual learner variables: i.e. proficiency, foreign language aptitude, strength of motivation, L2 self-concept, perfectionism, and competitiveness, as potential predictors of foreign language anxiety. The research found that foreign language aptitude and motivation were not significantly related to foreign language anxiety. The squared partial correlation value for motivation is below $2 \%$, in which indicates a very small, almost negligible effect size. This is similar to the present study in which found that the partial correlation value for motivation is only $1.3 \%$. The result of the additional data shows that students' interest of the language is the main reason in choosing the foreign language to study at the first place, followed by the prospect of the work in the future. In the case of Japanese, there are 64\% $(N=30)$ students who interested in the language itself. Although it indicates a tendency of high motivation, the students of Japanese, in fact, have the highest level of foreign language anxiety compared to Korean, Arabic, French, and English students. Young (1991) suggests that when belief and reality clash, the anxiety is more likely to occur. The great expectation students had about the foreign language of their interest encountered the reality they are facing in the learning process, including the level of difficulty of the language. It resulted in the occurrence of foreign language anxiety.

Furthermore, Young explains that anxiety also relates to student-teacher interactions and classroom procedures. The present study revealed that student's perception of teacher's behaviors significantly affects foreign language learning anxiety, in which the more negative the perception is, the more anxious the students would be. The additional data results also showed similar conclusion, where most students attributed the situation causing anxiety to teacher-related and classroom-related factors. Some of the teachers' behaviors perceived negatively by the students are discouraged comments made by teachers whenever students made errors, the teachers were too dominating inside the classroom, and the teaching methods did not help them understand the materials. Whilst, the classroom-related factor included when the students had to do the presentation without preparation, when their names were mentioned by the teacher and were asked to answer or to explain the material, and when the other classmates have already understood the material while he/she has not. MacIntyre and Gardner (1991) proposed that learners do not begin the language learning experience with language anxiety. Only after the development of attitudes and emotions regarding the language learning experience, language anxiety may occur. Based on the argument, it is inferred that the problem is more emphasized in the language learning experience, such 
as teacher's methodology or classroom procedure, instead of the students. Besides, the environment where the learning process is being conducted is also an important factor to be considered in relation to the occurrence of foreign language anxiety.

However, the present study also revealed that most students blame themselves as the one who is responsible for the anxiety, in spite of the fact that teacher-related situation is the main cause of the anxiety itself. The result suggests that the Indonesian students may feel reluctant to attribute the cause of emotion-eliciting events directly to other people, especially those with higher authority, such as teachers. It might reflect a socio-cultural characteristic of Indonesian students, as well as Asian students in general. Recent research conducted by Yue and Le (2010) proposed that Asian students view the teacher as an authority and a model, and also valued modesty as a virtue, so that majority of Asian students are modest and restrained. This characteristic may restrain students to put the blame directly on teacher, and assign the responsibility for the occurrence of the anxiety to themselves instead.

Lastly, significant contribution of external-related factor, namely student's perception of teacher's behaviors, to predict foreign language anxiety in the present study may also reflect socio-cultural context among foreign language learners in Asian countries. Masuda et al. (2008) in their research on Japanese and American subjects proposed that the perception of Japanese people is greatly influenced by their surroundings, and it may represent the characteristic of Asian people. The result of the present study also suggests the similar proposition.

\section{Conclusion}

The finding of the study confirms that Japanese learners have the highest foreign language anxiety level, followed by Arabic, French, Korean, and English learners. The different writing system of Japanese, including the using of three different kinds of alphabets in the same time, and the gradual increasing of difficulty as the learners move to intermediate and advanced level, are some factors contribute to it. There is also a difference in foreign language anxiety levels between Latin languages (English and French) and non-Latin languages (Japanese, Korean, and Arabic), in which the non-Latin one has a greater anxiety level. Besides the different writing system factor, the fact that English is the most common foreign language learned in Indonesia, in which many students of English also are engaging in informal English language institutes, makes English learners less anxious than other foreign language learners.

Students' motivation and their perception of teachers' behaviors do not simultaneously affect foreign language anxiety of Indonesian undergraduate students. As a matter of fact, it shows only a very small contribution to the foreign language anxiety. Furthermore, students' motivation in language learning is not a predictor of foreign language anxiety of Indonesian undergraduate students. One of the explanations for it is that the external factors, for example, classroom environment, give bigger influence than the internal one, such as motivation, for most of the Indonesian students.

On the other hand, students' perception of teachers' behaviors is one of the predictors of foreign language anxiety of Indonesian undergraduate students. The explanation is similar with the previous one, especially among Japanese learners, in which almost half the students participated in the study attribute teacher's behaviors as the source of their anxiety in foreign language classroom. The learning procedures and 
environment inside the classroom also contribute to the occurrence of the foreign language anxiety of the students.

\section{Recommendations}

The present study also proposes some recommendations for further research of foreign language anxiety and for the practitioner of foreign language teaching. The relationship between foreign language anxiety and other predictive variables found in other researches, i.e. student's self-perception, competitiveness, perfection, etc., needs to be further explored, especially within the context of Indonesian students. Furthermore, teachers, especially in Japanese class, need to assess their approach in error correction as well as their behaviors toward students. The present study found that teacher's behaviors, such as discouraged comments and harsh manner in correcting students' language errors, over-dominating inside the classroom, and inflexible teaching method that make it hard to understand the materials, were related to a higher level of foreign language anxiety. Young (1991) suggested that teachers need to be more friendly, relaxed and patient, made students feel more comfortable, encourage students to speak out, and emphasize that mistakes are part of language learning process. Teachers can do more pair work or small group work and language games to reduce foreign language anxiety. Working in pairs or small group provides a lot of opportunities for students to practice their foreign language skills, to help each other, and to gradually build their self-confidence in speaking in front of others.

\section{Additional file}

Additional file 1: Questionnaires employed in the study (in Indonesian language). (DOCX 28 kb)

Acknowledgements

Authors would like to thank all participants in this study, as well as teachers and language departments who gave their permission and support for us to conduct this study.

Funding

Authors confirm that there has been no significant financial support/funding for this work that could have influenced its outcome.

Availability of data and materials

Data will be available upon request.

Authors' contributions

FD conceptualized the paper and initiated discussions with SW to conduct research on individual differences of second/foreign language learners. FD consulted regularly with SW through all stages of this study, from the development of research plan, questionnaires, the analysis of data, to the discussion of research findings and conclusion. FD wrote the first draft of the paper and SW provided feedback for improvements. Both authors read and approved the final manuscript.

Ethics approval and consent to participate

Authors declare that they have obtained informed consent from all participants prior to the study.

Competing interests

The authors declare that they have no competing interests.

\section{Publisher's Note}

Springer Nature remains neutral with regard to jurisdictional claims in published maps and institutional affiliations.

\section{Author details}

${ }^{1}$ Japanese Language Program, Sekolah Vokasi, Universitas Gadjah Mada, Yogyakarta, Indonesia. ${ }^{2}$ Graduate School of International Culture and Communication Studies (GSICCS) Waseda University, 1-6-1 Nishiwaseda, Shinjuku, Tokyo 169-8050, Japan. ${ }^{3}$ Faculty of Psychology, Universitas Gadjah Mada, Bulaksumur, Yogyakarta 55281, Indonesia. 
Received: 5 February 2018 Accepted: 31 August 2018

Published online: 19 September 2018

\section{References}

Bandura, A. (1997). Self-efficacy: The exercise of control. New York: W.H. Freeman and Company

Bunkacho [Agency for Cultural Affairs] (2010). [List of kanji characters of general use]. Tokyo: Agency for Cultural Affairs Government of Japan. Retrieved from http://www.bunka.go.jp/kokugo_nihongo/sisaku/joho/joho/kijun/naikaku/kanji/ index.html. Accessed 4 Feb 2018

Duxbury, J. G., \& Tsai, L. (2010). The effects of cooperative learning on foreign language anxiety: A comparative study of Taiwanese and American universities. International Journal of Instruction, 3(1), 3-18.

Elkhafaifi, H. (2005). Listening comprehension and anxiety in the Arabic language classroom. Modern Language Journal, 89(2), 206-220.

Gardner, R. C. (1985). The attitude/motivation test battery: Technical report. A revised version. Ontario: University of Western Ontario.

Gardner, R. C., \& Maclntyre, P. D. (1993). A student's contributions to second language learning. Part II: Affective variables. Language Teaching, 26, 1-11.

Horwitz, E. K., Horwitz, M. B., \& Cope, J. (1986). Foreign language classroom anxiety. The Modern Language Journal, 70(2) $125-132$.

Katsuhisa, H., \& Masahide, S. (2006). New orientations in language learning motivation: Intrinsic/extrinsic motivation and self-determination theory. Kyouka Kyouiku Gakuronshuu, 3, 37-48.

Kitano, K. (2001). Anxiety in the college Japanese language classroom. The Modern Language Journal, 85, 549-566.

Kondo, Y. (2005). A study on relationship between language anxiety and proficiency: In a case of Japanese learners of English, $10^{\text {th }}$ Pan-Pacific Association of Applied Linguistic Seminar Proceedings (pp. 129-138).

Liu, M., \& Huang, W. (2011). An exploration of foreign language anxiety and English learning motivation. Education Research International, 2011(1), 1-8.

Maclntyre, P. D. (1995). How does anxiety affect second language learning? A reply to Sparks and Ganschow. The Modern Language Journal, 79, 90-99.

MacIntyre, P. D. (2002). Motivation, anxiety, and emotion in second language acquisition. In P. Robinson (Ed.), Individual differences and instructed language learning (pp. 45-68). Amsterdam: John Benjamins Publishing Company.

Maclntyre, P. D., \& Gardner, R. C. (1991). Methods and results in the study of anxiety and language learning: A review of the literature. Language Learning, 41(1), 85-117.

Masuda, T., Mesquita, B., Tanida, S., Ellsworth, P. C., Leu, J., \& Veerdonk, E. V. (2008). Placing the face in context: Cultural differences in the perception of facial emotion. Journal of Personality and Social Psychology, 94(3), 365-381.

Noels, K. A. (2001). Learning Spanish as a second language: Learners' orientations and perception of their teachers' communication styles. Language Learning, 51(1), 107-144.

Noels, K. A., Clément, R., \& Pelletier, L. G. (1999). Perceptions of teachers' communicative style and students' intrinsic and extrinsic motivation. The Modern Language Journal, 83(1), 23-34.

Noels, K. A., Pelletier, L. G., Clément, R., \& Vallerand, R. J. (2003). Why are you learning a second language? Motivational orientations and self-determination theory. Language Learning, 53, 33-63.

Pelletier, L. G., \& Vallerand, R. J. (1996). Supervisors' belief and subordinates' intrinsic motivation: A behavioral confirmation analysis. Journal of Personality and Social Psychology, 71(2), 331-340.

Rodríguez, M., \& Abreu, O. (2003). The stability of general foreign language classroom anxiety across English and French. The Modern Language Journal, 87, 365-374.

Saito, Y., Garza, T. J., \& Horwitz, E. K. (1999). Foreign language reading anxiety. Modern Language Journal, 83, 202-218.

Saito, Y., \& Samimy, K. (1996). Foreign language anxiety and language performance: A study of learner anxiety in beginning, intermediate, and advanced-level college students of Japanese. Foreign Language Annals, 29(2), 239-251.

Sila, A. Y. (2010). Young adolescent students' foreign language anxiety in relation to language skills at different levels. The Journal of International Social Research, 3(11), 83-91.

Tajima, M. (2002). Motivation, attitudes, and anxieties toward learning English as a foreign language: A survey of Japanese university students in Tokyo. Gengo no Sekai, 20(1/2), 115-155.

Tóth, Z. (2007). Predictors of foreign language anxiety: Examining the relationship between anxiety and other individual learner variables. In J. Horváth \& M. Nikolov (Eds.), UPRT 2007: Empirical Studies in English Applied Linguistics (pp. 123-148). Pécs: Lingua Franca Csoport.

Tsiplakides, I., \& Keramida, A. (2009). Helping students overcome foreign language speaking anxiety in the English classroom: Theoretical issues and practical recommendations. International Education Studies, 2(4), 39-44.

Williams, K. E., \& Andrade, M. R. (2008). Foreign language learning anxiety in Japanese EFL university classes: Causes, coping, and locus of control. Electronic Journal of Foreign Language Teaching, 5(2), 181-191.

Yoshida, K. (2010). Coping with anxiety in the foreign language classroom: Japanese students on study-abroad language courses in the UK. The Journal of Language and Culture, 14, 59-80.

Young, D. J. (1991). Creating a low-anxiety classroom environment: What does language anxiety research suggest? The Modern Language Journal, 75(4), 426-439.

Yue, Y., \& Le, T. (2010). Cultural adaptation of Asian students in Australia. Proceedings from AARE 2009: International Education Research Conference. Melbourne: Australian Association for Research in Education. 